\title{
Influence of Organic Amendment on Soil Respiration and Maize Productivity in a Semi-Arid Environment
}

\author{
Shirley Lamptey ${ }^{1,2,3}$, Junhong Xie ${ }^{1,2}$, Lingling $\mathrm{Li}^{1,2, * \mathbb{C}}$, Jeffrey A. Coulter ${ }^{4}(\mathbb{D}$ and \\ Padma Shanthi Jagadabhi ${ }^{5}$ (i) \\ 1 Gansu Provincial Key Laboratory of Aridland Crop Science, Lanzhou 730070, China; \\ naalamp2009@yahoo.com (S.L.); xiejh@gsau.edu.cn (J.X.) \\ 2 College of Agronomy, Gansu Agricultural University, Lanzhou 730070, China \\ 3 University for Development Studies, P.O. Box TL 1882 Tamale, Ghana \\ 4 Department of Agronomy and Plant Genetics, University of Minnesota, St. Paul, MN 55108, USA; \\ jeffcoulter@umn.edu \\ 5 International Crops Research Institute for Semi-Arid Tropics (ICRISAT), Patancheru 502324, India; \\ j.Shanthi@cgiar.org \\ * Correspondence: lill@gsau.edu.cn; Tel.: +86-931-760-3751
}

Received: 6 September 2019; Accepted: 30 September 2019; Published: 3 October 2019

\begin{abstract}
Soil degradation and $\mathrm{C}$ emissions are a threat to sustainable agriculture in many arid and semi-arid areas. For sustainable agriculture, the influence of soil amendments on crop production and soil respiration has been a key focus of research. A three-year field study to assess how soil amendments influence soil properties, soil respiration (Rs), and yield of maize (Zea mays L.) was conducted. Treatments were: no amendment (NA), chemical fertilizer (CF), swine (Sus scrofa L.) manure (SM), maize stover (MS), and swine manure + chemical fertilizer (SC). Soil amendment (CF, SM, MS, and SC) consistently produced greatest grain yield and aboveground biomass, which averaged 38 and $34 \%$ greater than NA, respectively. No amendment reduced Rs by an average of $12 \%$ compared to amendment treatments. Enhanced grain yield with soil amendment resulted in increased carbon emission efficiency (CEE) with SC $>$ MS $>$ CF $>$ SM $>$ NA. Across years, SC decreased soil bulk density by $13 \%$ and increased CEE, soil total C, and soil hydraulic conductivity by 52,19 , and $21 \%$, respectively, compared to NA. These results demonstrate the viability of swine manure + chemical fertilizer at $200 \mathrm{~kg} \mathrm{~N} \mathrm{ha}^{-1}$ as a soil amendment for improved CEE and advancing sustainable maize production in semi-arid rainfed environments.
\end{abstract}

Keywords: soil amendment; chemical fertilizer; soil respiration; carbon emission efficiency; maize

\section{Introduction}

Maize (Zea mays L.) is an important crop in northern China. The planted area to maize in this region is about 20 million ha, representing $~ 70 \%$ of China's total maize area [1]. In recent years, swine production in China has experienced growth motivated by favorable government policies [2,3], resulting in a substantial increase in the demand for maize grain $[3,4]$.

Agriculture in the semi-arid Loess Plateau of northern China is of crucial importance in achieving food security [5]. However, it depends mainly on precipitation, which averages about $450 \mathrm{~mm}$ and exhibits high spatial and temporal variation [6]. Maize production was not possible without use of special management practices in the semi-arid Loess Plateau [7] due to high evaporation, limited rainfall, and low accumulated soil temperature. In an attempt to advance maize production for food security in this region, a complete plastic mulching technique was introduced [8] to decrease evaporation, increase soil temperature, and soil moisture [9]. This system can improve harvest surface 
runoff from rainfall $[8,10]$, reduce evaporation [11], and increase accumulated soil temperature [8], thereby improving water use efficiency and productivity of maize [12] and enabling continuous maize production. Adopting this technology has led to increased maize yield and profitability for farmers in semi-arid rainfed environments [8]. Consequently, this technology is widely used in maize production in the semi-arid Loess Plateau [13] and on about 19\% of total arable land (130 million ha) in China [14]. However, there are concerns regarding the long-term sustainability of this practice. Greater crop yields increase water and nutrient consumption [15] and could reduce the ability to sustain maize production in the long run without special fertilization practices. Responses to these challenges include fertilization programs with manures [16] to increase soil fertility $[16,17]$. Rational organic amendment application is among the most important measures to increase water use efficiency and grain yield of maize $[18,19]$ and balance soil nutrients [16].

Soil amendments can significantly affect soil microbial populations and their activity, subsequently influencing soil $\mathrm{CO}_{2}$ emission [20,21]. In addition, differences in soil moisture and temperature resulting from soil amendments can influence soil $\mathrm{CO}_{2}$ fluxes [22,23]. Maize is important for meeting the increasing demand for grain for livestock and human consumption [24]. To date, few studies report how productivity of grain-maize and $\mathrm{CO}_{2}$ emission are affected by soil amendment practices in semi-arid areas. This research is designed to: (1) evaluate the effects of soil amendment on grain yield and biomass production from maize, (2) determine the effects of soil amendment on carbon emission and efficiency, and (3) explore the underlying microbial mechanisms and the consequent effects of soil amendments on maize productivity and $\mathrm{CO}_{2}$ emission.

\section{Materials and Methods}

\subsection{Experimental Site}

The field experiment was conducted at Gansu Agricultural University Experimental station $\left(35^{\circ} 28^{\prime} \mathrm{N}, 104^{\circ} 44^{\prime} \mathrm{E}, 1971 \mathrm{~m}\right.$ above sea level), Dingxi, in northwestern China. Soil at the experimental site is sandy-loam and low in fertility. The soil is classified as Calcaric Cambisol [25]. Soil properties (chemical and physical) prior to initiation of the experiment in 2012 are reported in Table 1.

Table 1. Soil chemical and physical properties prior to sowing in 2012.

\begin{tabular}{|c|c|c|c|c|c|}
\hline Soil Layer (cm) & $\underset{\text { (Water) }}{\mathrm{pH}}$ & $\begin{array}{l}\text { Bulk Density } \\
\left(\mathrm{Mg} \mathrm{m}^{-3}\right)\end{array}$ & $\begin{array}{c}\text { Organic C } \\
\left(\mathrm{g} \mathrm{kg}^{-1}\right)\end{array}$ & $\begin{array}{r}\text { Total N } \\
\left(\mathrm{g} \mathrm{kg}^{-1}\right)\end{array}$ & $\begin{array}{r}\text { Total P } \\
\left(\mathrm{g} \mathrm{kg}^{-1}\right)\end{array}$ \\
\hline $0-5$ & 8.33 & 1.19 & 9.91 & 1.05 & 0.82 \\
\hline $5-10$ & 8.32 & 1.22 & 8.96 & 1.05 & 0.74 \\
\hline $10-30$ & 8.37 & 1.28 & 8.89 & 0.94 & 0.70 \\
\hline
\end{tabular}

Values are means $(n=3)$.

Before 2012, the experimental site had been in long-term annual potato (Solanum tuberosum L.) production using conventional tillage practices. These included moldboard plowing to a depth of $20 \mathrm{~cm}$ after harvest usually in October and field cultivating to a depth of $10 \mathrm{~cm}$ prior to sowing in March-April. Long-term (1986-2003) annual precipitation at the experimental site averaged $391 \mathrm{~mm}$ and ranged from 246 to $564 \mathrm{~mm}$. Almost $60 \%$ of this precipitation occurs between July and September. Long-term daily air temperatures ranged from $-22^{\circ} \mathrm{C}$ in January to $38^{\circ} \mathrm{C}$ in July. Long-term annual accumulated temperature $>10^{\circ} \mathrm{C}$ is $2239^{\circ} \mathrm{C}$ and annual radiation is $5929 \mathrm{MJ} \mathrm{m}^{-2}$ with $2477 \mathrm{~h}$ of sunshine. The research reported in this article is from the 2014, 2015, and 2016 cropping seasons, with cumulative precipitation during the crop growing season at the experimental site being 280, 274, and $227 \mathrm{~mm}$, respectively (Figure 1). Air temperature and relative humidity with vapor pressure deficit during the crop growing season at the experimental site are shown in Figures 2 and 3, respectively. 


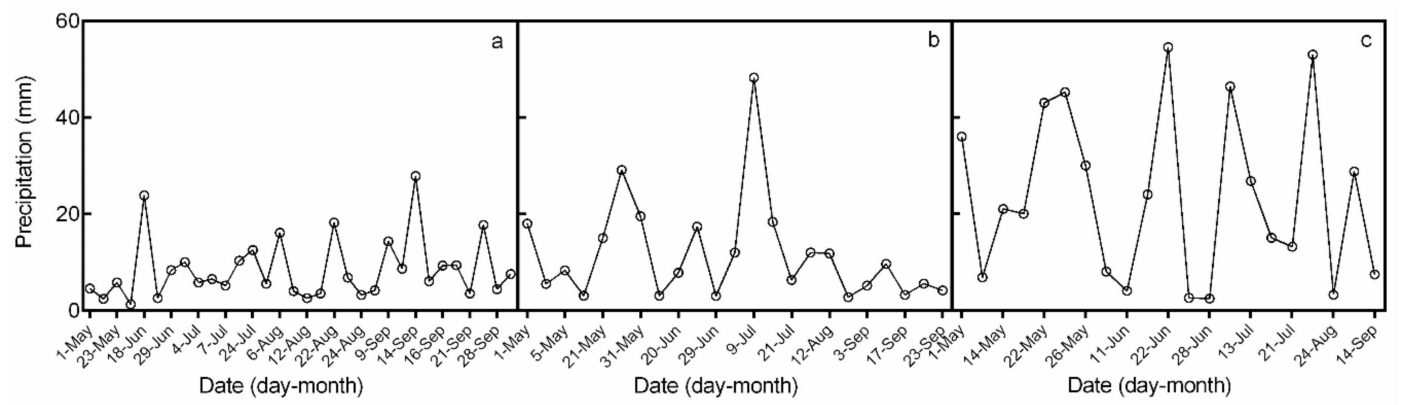

Figure 1. Daily precipitation during the 2014 (a), 2015 (b), and 2016 (c) growing seasons.

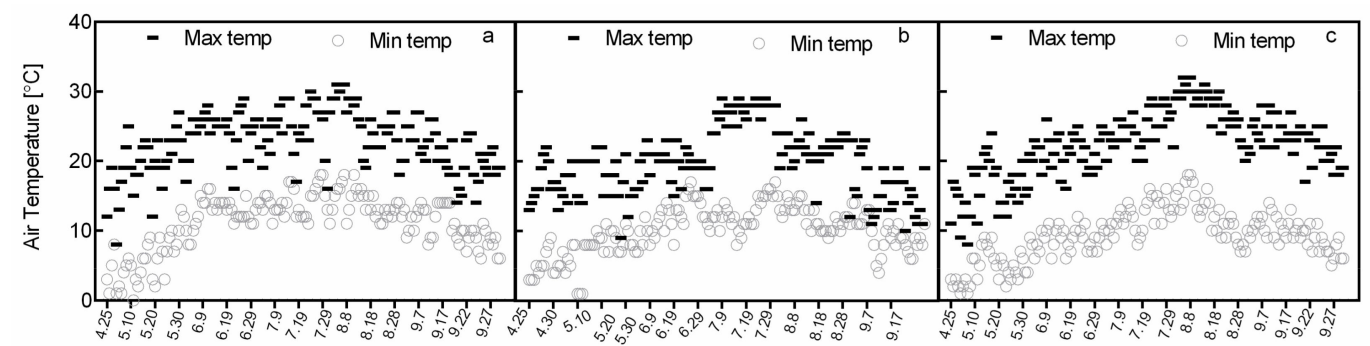

Figure 2. Minimum and maximum air temperature for (a) 2014, (b) 2015 and (c) 2016 cropping season.

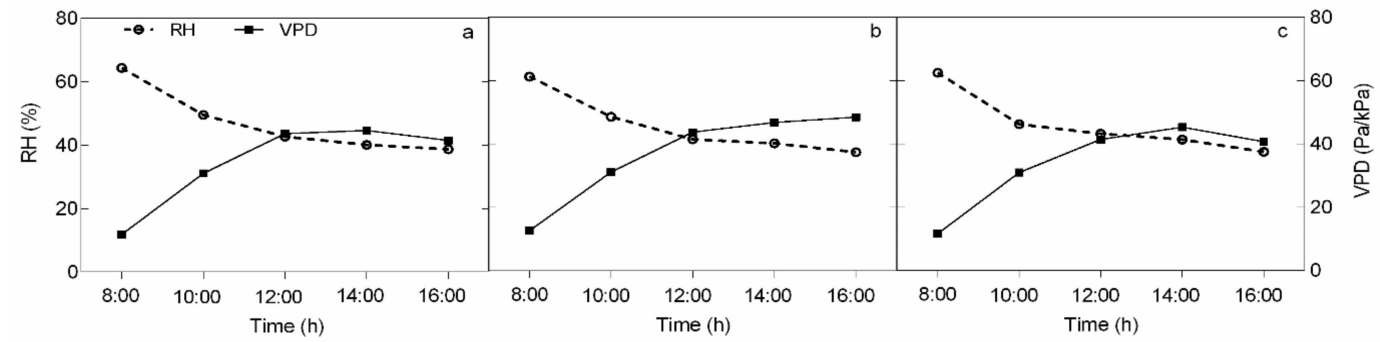

Figure 3. Diurnal variations in relative humidity (RH) and vapor pressure deficit (VPD) in 2014 (a), 2015 (b) and 2016 (c) recorded between 8:00 and 16:00 h. Symbols are: (○) Relative humidity and ( $\square$ ) vapor pressure deficit.

\subsection{Experimental Design}

The experiment was laid in a randomized complete block design with three replications of five treatments: no amendment (NA), chemical fertilizer (CF) consisting of $200 \mathrm{~kg} \mathrm{~N} \mathrm{ha}^{-1}$ as urea (46-0-0 of $\left.\mathrm{N}-\mathrm{P}_{2} \mathrm{O}_{5}-\mathrm{K}_{2} \mathrm{O}\right)$ plus $150 \mathrm{~kg} \mathrm{P}_{2} \mathrm{O}_{5} \mathrm{ha}^{-1}$ using calcium super phosphate (0-16-0 of N-P $\left.\mathrm{P}_{2} \mathrm{O}_{5}-\mathrm{K}_{2} \mathrm{O}\right)$, solid swine (Sus scrofa L.) manure (SM) applied at $10 \mathrm{mg} \mathrm{ha}^{-1}$, maize stover (MS) applied at $27 \mathrm{mg} \mathrm{ha}^{-1}$, and swine manure + chemical fertilizer (SC) consisting of $5 \mathrm{mg} \mathrm{ha}^{-1}$ of solid swine manure plus $100 \mathrm{~kg} \mathrm{~N} \mathrm{ha}^{-1}$ as urea and $75 \mathrm{~kg} \mathrm{P}_{2} \mathrm{O}_{5} \mathrm{ha}^{-1}$ as calcium super phosphate. All amendment treatments were applied at $200 \mathrm{~kg} \mathrm{~N} \mathrm{ha}^{-1}$. Maize stover was collected from the entire experimental area after harvest and mixed, air-dried, shredded, weighed, and applied to field plots for the MS treatment. Solid swine manure was obtained from a local farm and stored for 2 months prior to application. All amendments, including solid swine manure, maize stover, and chemical fertilizers, were evenly distributed each year on the soil surface in the spring and incorporated within 3 days of application by moldboard plowing at $20 \mathrm{~cm}$ depth. Representative samples of maize stover and manure were collected at the time of application and analyzed for nutrient concentration using an Elementar vario MACRO cube (Elementar, Hanau, Germany) (Table 2). 
Table 2. Average chemical composition of maize stover and swine manure used in 2014, 2015 and 2016.

\begin{tabular}{ccccccc}
\hline Amendment & Organic C & N & P & K & Ca & Mg \\
\hline \multicolumn{7}{c}{ \% } \\
\hline Maize stover & 47.5 & 0.74 & 0.38 & 0.45 & 0.55 & 0.74 \\
Swine manure & 39.9 & 2.23 & 1.74 & 1.92 & 2.74 & 0.54 \\
\hline \multicolumn{7}{c}{ Values are means $(n=3)}$.
\end{tabular}

Experimental plots measured $42.6 \mathrm{~m}^{2}(3 \times 14.2 \mathrm{~m})$ with $15 \mathrm{~cm}$ high $\times 40 \mathrm{~cm}$ wide narrow ridges, alternated with $10 \mathrm{~cm}$ high $\times 70 \mathrm{~cm}$ wide ridges. Colorless plastic film was used to cover all ridges to increase soil temperature, hasten crop emergence, and reduce evaporative losses. Holes were made through the film in furrows after the covering to facilitate collection of precipitation [26]. Plowing, ridging and mulching occurred at sowing and was the same for all treatments.

\subsection{Agronomic Practice}

Treatments for the experiment were imposed on the same plots in all years. All agronomic practices were equal among treatments, except for soil amendment application. Each year, maize (cv. Funong 821) was sown in alternating row distances of 0.7 and $0.4 \mathrm{~m}$ to a density of 52,000 plants ha $^{-1}$ on 29 April, 25 April and 30 April, and harvested on 2 October, 25 September and 20 September in 2014, 2015 and 2016, respectively. Weeds were controlled using herbicide during the period between harvest and before next cropping season. Hand weeding was used between sowing and harvest.

\subsection{Measurement and Calculation}

\subsubsection{Bulk Density and Total Porosity of Soil}

Soil samples for bulk density were collected (0-5 and 5-10 $\mathrm{cm}$ depth) immediately before application of amendment treatment in 2014, 2015 and 2016 using the beveled stainless steel ring method [27]. Total soil porosity $(\eta)$ was derived using soil bulk density as described by Paydar and Cresswell [28].

\subsubsection{Soil Water Content}

Each time soil respiration (Rs) was measured, soil water content in the $0-5$ and 5-10 cm layers was also measured using Jia et al. [29] oven drying method. Two samples were taken from each plot. Gravimetric soil water content obtained using oven dry method was multiplied by bulk density for the respective soil layer to obtain the volumetric water content. Reported soil water content values in this study correspond to the mean of the two depths.

\subsubsection{Soil Hydraulic Conductivity}

Prior to soil tillage in the spring of 2014 and 2016, soil hydraulic conductivity (Ksat) was determined using the disc permeameter method and equation by Liu et al. [30]. This was done at two locations per plot.

\subsubsection{Soil Total Carbon}

Soil samples for determination of total soil C were collected prior to sowing in 2014 and 2015 using a soil corer ( $4.9 \mathrm{~cm}$ diameter). Organic residues $>2 \mathrm{~mm}$ were removed from samples. These samples were air dried, ground and made to pass through a 2-mm sieve. They were subsequently sub-sampled and again made to pass through a $0.25-\mathrm{mm}$ sieve. The samples were then analyzed for total $\mathrm{C}$ by combustion using an Elementar vario MACRO cube (Elementar, Hanau, Germany). Soil total C was not determined in 2016 due to time constraint. 


\subsubsection{Grain and Biomass Yield of Maize}

Grain maize and aboveground biomass were manually harvested at physiological maturity from an area of $13.2 \mathrm{~m}^{2}(4 \times 3.3 \mathrm{~m})$ per plot. After harvest, grains were separated, weighed, and yield in kilograms per hectare were extrapolated and reported. Grain yield and aboveground biomass were determined on a dry-matter basis after oven drying the crop samples at $105^{\circ} \mathrm{C}$ for $45 \mathrm{~min}$ and subsequently to constant mass at $85^{\circ} \mathrm{C}$ [26].

\subsubsection{Soil Respiration}

Measurement on soil respiration was done eleven (11) times per year from sowing (late April) to maize physiological maturity (late September) on about 2-wk intervals using EGM-4 (British PP Systems) portable $\mathrm{CO}_{2}$ analyzer. Measurements were done under the plastic film at three locations in each plot between 8:00-12:00 $\mathrm{h}$. This according to Alves et al. [31] was to effectively capture microbial activity on diurnal pattern.

\subsubsection{Carbon Emission}

Carbon emission (CE) was arrived at using soil respiration (Rs) measurement into equation described by Zhai et al. [32]:

$$
\mathrm{CE}=\sum\left[\left(\frac{\mathrm{Rs}_{i+1}+\mathrm{Rs}_{i}}{2}\right) \times\left(t_{i+1}-t_{i}\right) \times 0.1584 \times 24\right] \times 0.2727 \times 10
$$

where soil respiration is $\mathrm{Rs}\left(\mu \mathrm{mol} \mathrm{CO} \mathrm{Cm}^{-2} \mathrm{~s}^{-1}\right)$ measured once in every $2 \mathrm{wk}$ during the growing season, $i+1$ and $i$ represent the previous and the current sampling date, respectively, and $t$ represent days after sowing.

\subsubsection{Carbon Emission Efficiency}

Carbon emission efficiency (CEE) was calculated to quantify unit of carbon emission per grain yield. This was done using carbon emission into equation described by Qin et al. [33]:

$$
\mathrm{CEE}=\frac{\text { grain yield }\left(\mathrm{kg} \mathrm{ha}^{-1}\right)}{\text { carbon emission }\left(\mathrm{kg} \mathrm{ha}^{-1}\right)}
$$

\subsubsection{Net Primary Productivity}

Net primary productivity (NPP) was calculated using the method of [34]:

$$
\mathrm{NPP}=\mathrm{C}_{\mathrm{P}}+\mathrm{C}_{\mathrm{S}}+\mathrm{C}_{\mathrm{R}}+\mathrm{C}_{\mathrm{E}}
$$

where $C_{P}$ is plant Carbon $(C)$ in the harvested maize grain, $C_{S}$ is plant carbon $(C)$ in total aboveground biomass excluding the harvested product (i.e., maize cob + stover), $C_{R}$ is plant carbon $(C)$ in roots, and $C_{E}$ is plant carbon $(C)$ in extra-root material including root exudates. The Carbon input of these fractions were calculated using maize grain yield and aboveground biomass measured in this experiment and assuming that carbon concentration of all the plant part was $0.45 \mathrm{~kg} \mathrm{~kg}^{-1}$ [34].

\subsection{Statistical Analysis}

The effects of treatment, year, and the interaction between them on the above measured parameters were evaluated using analysis of variance at $p \leq 0.05$ with statistical analysis software (SPSS 22.0, IBM Corp., Chicago, IL, USA). Treatment and year were considered fixed effect, whereas block was considered as a random effect. Differences between means were determined using the least 
significant difference test. The associations between dependent variables were assessed using Pearson's correlation coefficient.

\section{Results}

\subsection{Soil Water Content and Properties as Influenced by Soil Amendment}

Soil amendment significantly affected soil water content in the depth of 0-10 cm on eight, six, and four occasions in 2014, 2015, and 2016, respectively (Figure 4).

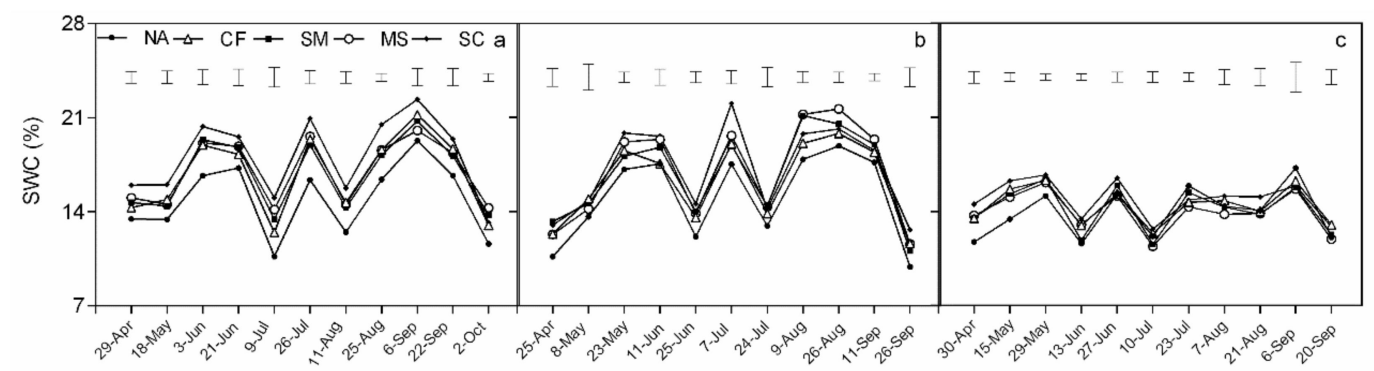

Figure 4. Volumetric Soil water content (SWC) in the 0-10 cm layer during the 2014 (a), 2015 (b), and 2016 (c) growing seasons as influenced by soil amendment treatment. NA, no amendment; CF, chemical fertilizer; SM, swine manure; MS, maize stover; and SC, swine manure + chemical fertilizer. Vertical bars denote LSD (0.05).

Averaged across sampling times, soil water content was least with NA and greatest with SC. Soil water content with SC and NA were 18.1 and 14.9 in 2014, 17.2 and 15.0 in 2015, and 14.9 and 13.9 in 2016, respectively (Figure 5a-c).

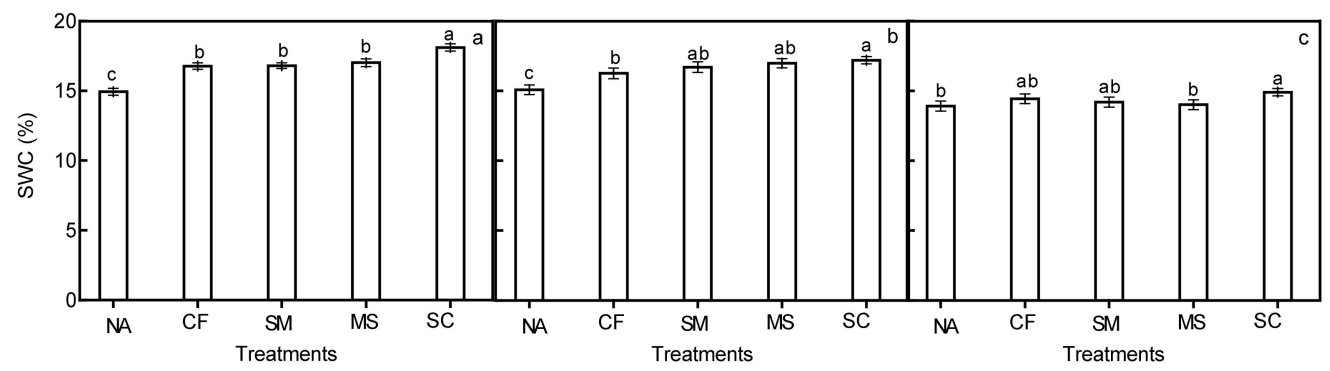

Figure 5. Mean soil water content (SWC) by soil amendment treatment in maize in 2014 (a), 2015 (b), and 2016 (c). NA, no amendment; CF, chemical fertilizer; SM, swine manure; MS, maize stover; and SC, swine manure + chemical fertilizer. Within a year, bars with different letters are significantly different $(p \leq 0.05)$. Error bars denote standard errors.

Significant differences in $\rho_{b}$ and total $C$ among treatments within the $0-5$ and 5-10 $\mathrm{cm}$ layers were recorded (Table 3). Soil bulk density in the $0-10 \mathrm{~cm}$ layer of the SC treatment was 13, 12, 9, and 9\% less than that of the NA, CF, SM, and MS treatments, respectively. Soil C in the depth of 0-10 cm was significantly greater in amendment treatments compared to NA. Among the amendment treatments, soil $C$ in the $0-5$ and $5-10 \mathrm{~cm}$ layers of the SC treatment was greater by 13 and $11 \%$ in 2014 and 10 and $9 \%$ in 2015 compared to the $\mathrm{CF}$ treatment, respectively. 
Table 3. Bulk density $\left(\rho_{b}, \mathrm{~g} \mathrm{~cm}^{-3}\right)$, total porosity $(\mathrm{TP}, \%)$, and total carbon $(\mathrm{C}, \%)$ in the $0-5$ and $5-10 \mathrm{~cm}$ soil layers by soil amendment treatment in maize and year.

\begin{tabular}{cccccccccccc}
\hline \multirow{2}{*}{ Table } & \multicolumn{1}{c}{$\rho_{\boldsymbol{b}}$} & \multicolumn{4}{c}{$\mathbf{c}$} \\
\cline { 2 - 12 } & \multicolumn{2}{c}{$\mathbf{2 0 1 4}$} & \multicolumn{2}{c}{$\mathbf{2 0 1 5}$} & \multicolumn{2}{c}{$\mathbf{2 0 1 6}$} & \multicolumn{2}{c}{$\mathbf{2 0 1 4}$} & $\mathbf{2 0 1 5}$ \\
\cline { 2 - 12 } & $\mathbf{0 - 5}$ & $\mathbf{5 - 1 0}$ & $\mathbf{0 - 5}$ & $\mathbf{5 - 1 0}$ & $\mathbf{0 - 5}$ & $\mathbf{5 - 1 0}$ & $\mathbf{0 - 5}$ & $\mathbf{5 - 1 0}$ & $\mathbf{0 - 5}$ & $\mathbf{5 - 1 0}$ \\
\hline NA & 1.25 & 1.28 & 1.23 & 1.25 & 1.23 & 1.29 & 1.48 & 1.39 & 1.52 & 1.48 \\
CF & 1.24 & 1.28 & 1.22 & 1.24 & 1.21 & 1.22 & 1.54 & 1.52 & 1.61 & 1.55 \\
SM & 1.21 & 1.23 & 1.14 & 1.20 & 1.21 & 1.25 & 1.69 & 1.59 & 1.68 & 1.71 \\
MS & 1.22 & 1.23 & 1.15 & 1.24 & 1.18 & 1.21 & 1.74 & 1.63 & 1.71 & 1.74 \\
SC & 1.06 & 1.10 & 1.07 & 1.13 & 1.04 & 1.25 & 1.76 & 1.71 & 1.78 & 1.74 \\
LSD (0.05) & 0.03 & 0.04 & 0.01 & 0.06 & 0.02 & 0.04 & 0.09 & 0.12 & 0.05 & 0.03 \\
\hline
\end{tabular}

NB: No Amendment, CF: Chemical fertilizer, SM: Swine manure, MS: Maize stover, SC: Swine manure + chemical fertilizer. Footnote: Soil total C was not measured in 2016.

Swine manure + chemical fertilizer also increased $\mathrm{K}_{\text {sat }}$ in comparison to NA by 29 and $13 \%$ in 2014 and 2016, respectively (Figure 6).

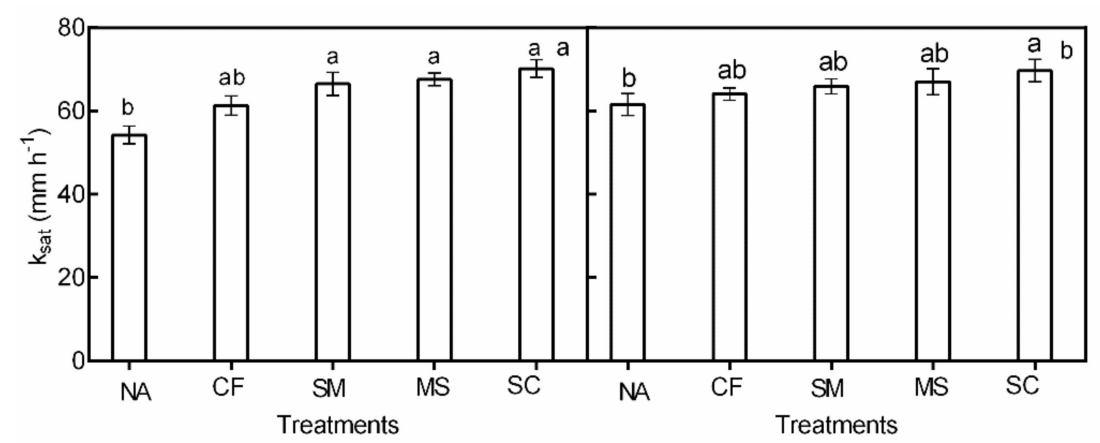

Figure 6. Soil hydraulic conductivity $\left(\mathrm{K}_{\mathrm{sat}}\right)$ measured in 2014 (a) and 2016 (b) by soil amendment treatment in maize. NA, no amendment; $\mathrm{CF}$, chemical fertilizer; SM, swine manure; MS, maize stover; and SC, swine manure + chemical fertilizer. Within a year, bars with different letters are significantly different $(p \leq 0.05)$. Error bars denote standard errors.

\subsection{Main Grain Yield and Biomass as Influenced by Soil Amendment}

Grain yield of maize and aboveground biomass were significantly affected by treatment, year, and the treatment $\times$ year interaction (Table 4 ). Averaged across years, grain yield of the amendment treatments was greater than that of the NA treatment. Swine manure + chemical fertilizer produced the greatest grain yield $\left(7760 \mathrm{~kg} \mathrm{ha}^{-1}\right)$, which was $6,12,15$, and $74 \%$ greater than that with CF, MS, $\mathrm{SM}$, and NA, respectively. There were significant differences in maize aboveground biomass among treatments in all years. Compared to NA, SC increased biomass by 69,62 , and $46 \%$ in 2014, 2015, and in 2016, respectively. Biomass with CF was not different from that with SC in any year. 
Table 4. Yield and aboveground biomass of maize by soil amendment treatment in 2014, 2015, and 2016.

\begin{tabular}{|c|c|c|c|c|c|c|}
\hline \multirow{2}{*}{ Treatment } & \multicolumn{3}{|c|}{ Grain Yield (kg ha $\left.{ }^{-1}\right)$} & \multicolumn{3}{|c|}{ Aboveground Biomass $\left(\mathrm{kgha}^{-1}\right)$} \\
\hline & 2014 & 2015 & 2016 & 2014 & 2015 & 2016 \\
\hline NA & 5322 & 4594 & 3459 & 16,012 & 15,098 & 7098 \\
\hline $\mathrm{CF}$ & 8228 & 8103 & 5805 & 24,846 & 24,534 & 11,809 \\
\hline SM & 7888 & 6732 & 5641 & 23,394 & 22,800 & 11,104 \\
\hline MS & 7550 & 7433 & 5768 & 22,020 & 19,573 & 11,282 \\
\hline SC & 8900 & 8209 & 6156 & 27,106 & 24,430 & 13,123 \\
\hline LSD (0.05) & 1332 & 1450 & 1094 & 4214 & 3880 & 2222 \\
\hline \multicolumn{7}{|c|}{ Source of variation } \\
\hline Treatment $(\mathrm{T})$ & \multicolumn{3}{|c|}{$* * *$} & \multicolumn{3}{|c|}{$* * *$} \\
\hline Year $(Y)$ & \multicolumn{3}{|c|}{$* * *$} & \multicolumn{3}{|c|}{$* * *$} \\
\hline $\mathrm{T} \times \mathrm{Y}$ & \multicolumn{3}{|c|}{ * } & \multicolumn{3}{|c|}{$* *$} \\
\hline
\end{tabular}

* Significant at the 0.05 probability level, ${ }^{* *}$ Significant at the 0.01 probability level, ${ }^{* * *}$ Significant at the 0.001 probability level.

\subsection{Soil Respiration, Carbon Emission Efficiency, and Net Primary Production as Affected by Soil Amendment}

Soil respiration flux observed throughout the sampling period had a similar pattern for all treatments and for the three study years (Figure 5). Soil respiration increased with maize maturity until the kernel milk stage and then decreased. Greatest values $\left(0.88,0.90\right.$ and $\left.0.78 \mu \mathrm{mol} \mathrm{m}{ }^{-2} \mathrm{~s}^{-1}\right)$ were recorded on 8 August 2014, 24 July 2015, and 7 August 2016, respectively (Figure 7a-c). Soil respiration differed significantly among treatments at eight, five and six sampling times in 2014, 2015, and 2016, respectively. The amendment treatments had greater Rs compared to NA. Averaged across years Rs with NA was 15, 9, 7, and 15\% less than that compared with CF, SM, MS, and SC, respectively (Figure 7).

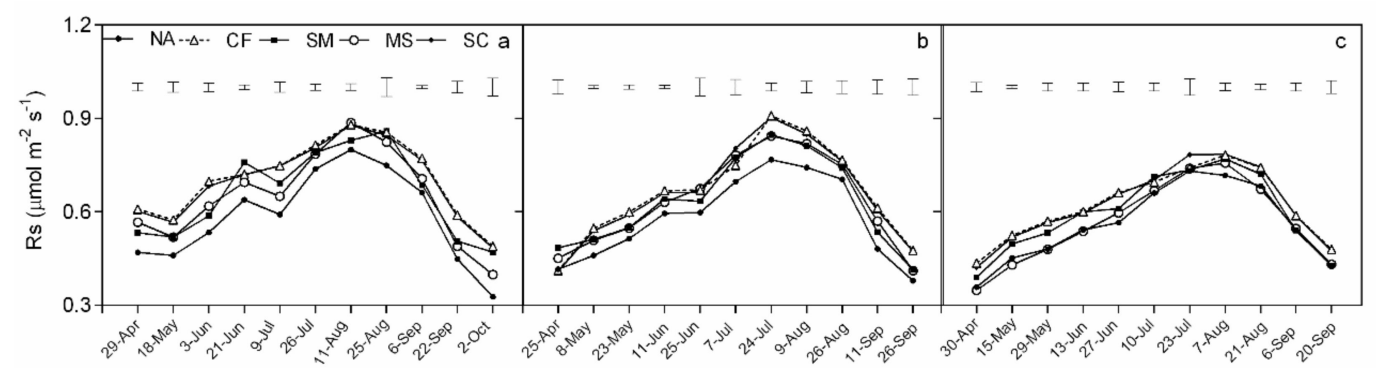

Figure 7. Soil respiration (Rs) during the 2014 (a), 2015 (b), and 2016 (c) growing seasons by soil amendment treatment in maize. NA, no amendment; CF, chemical fertilizer; SM, swine manure; MS, maize stover; and SC, swine manure + chemical fertilizer. Error bars denote LSD (0.05).

Increased Rs in amended soils resulted in significantly greater CE $\left(1029 \mathrm{~kg} \mathrm{ha}^{-1}\right)$ compared to NA (929 kg ha ${ }^{-1}$ ). Among the amended treatments, CF and SC produced the greatest CE (Table 5). Carbon emission efficiency also differed significantly among treatments. The four amendment treatment (CF, SM, MS and SC) averagely increased CEE by 32, 47 and 56\% in 2014, 2015 and 2016, respectively. 
Table 5. Growing season soil respiration (Rs, carbon emission (CE) and carbon emission efficiency (CEE)) by soil amendment treatment in maize in 2014, 2015, and 2016.

\begin{tabular}{|c|c|c|c|c|c|c|c|c|c|}
\hline \multirow{2}{*}{ Treatment } & \multicolumn{3}{|c|}{$\operatorname{Rs}\left(\mu \mathrm{mol} \mathrm{m} \mathrm{m}^{-2} \mathrm{~s}^{-1}\right)$} & \multicolumn{3}{|c|}{ CE (Kg ha $\left.{ }^{-1}\right)$} & \multicolumn{3}{|c|}{ CEE $\left(\mathrm{Kg} \mathrm{kg}^{-1}\right)$} \\
\hline & 2014 & 2015 & 2016 & 2014 & 2015 & 2016 & 2014 & 2015 & 2016 \\
\hline NA & 0.58 & 0.58 & 0.56 & 978 & 940 & 853 & 5.5 & 4.9 & 4.1 \\
\hline $\mathrm{CF}$ & 0.70 & 0.66 & 0.62 & 1166 & 1078 & 941 & 7.1 & 7.3 & 6.2 \\
\hline SM & 0.66 & 0.63 & 0.59 & 1090 & 1024 & 905 & 7.2 & 6.6 & 6.2 \\
\hline MS & 0.65 & 0.63 & 0.56 & 1079 & 1034 & 860 & 7.0 & 7.2 & 6.7 \\
\hline SC & 0.70 & 0.66 & 0.62 & 1156 & 1077 & 945 & 7.7 & 7.6 & 6.5 \\
\hline LSD (0.05) & 0.05 & 0.03 & 0.03 & 74.6 & 57.2 & 43.6 & 0.87 & 1.09 & 1.11 \\
\hline \multicolumn{10}{|c|}{ Source of variation } \\
\hline Treatment (T) & & $* * *$ & & & $* * *$ & & & $* * *$ & \\
\hline Year $(\mathrm{Y})$ & & $* * *$ & & & $* * *$ & & & $* *$ & \\
\hline $\mathrm{T} \times \mathrm{Y}$ & & $* *$ & & & $* *$ & & & ns & \\
\hline
\end{tabular}

Net primary production indicates the magnitude and turnover of $C$ and nutrient cycles in an ecosystem and was significantly affected by the interaction between treatment and year. Greatest NPP was obtained with CF, SM, and SC in all years $\left(49,000,46,000\right.$, and 20,000 kg C ha ${ }^{-1}$ year $^{-1}$ in 2014, 2015, and 2016, respectively), which was 57, 51 and 69\% greater than that with NA in 2014, 2015 and 2016, respectively (Figure 8a-c). Net primary production with MS was not significantly different than that with CF, SM, or SC in 2014 or 2016.

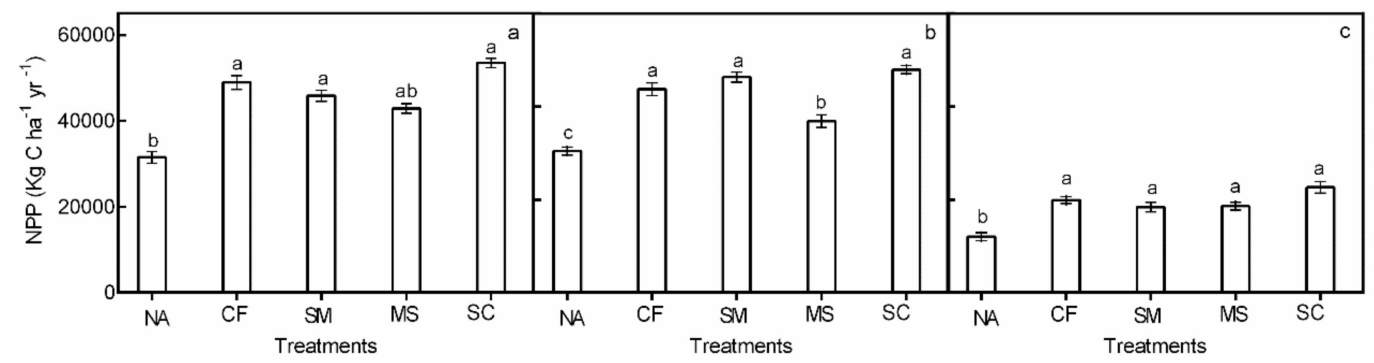

Figure 8. Net primary productivity (NPP) in 2014 (a), 2015 (b), and 2016 (c) by soil amendment treatment in maize. NA, no amendment; $\mathrm{CF}$, chemical fertilizer; SM, swine manure; MS, maize stover; and SC, swine manure + chemical fertilizer. Within a year, bars with different letters are significantly different $(p \leq 0.05)$. Error bars denote standard errors.

\section{Discussion}

\subsection{Grain Yield, Biomass, and Net Primary Production}

Management practices in agriculture can have significant effect on crop growth and productivity [35]. Swine manure + chemical fertilizer consistently produced greater maize grain yield and biomass than the other treatments. Kibunja et al. [36] reported enhanced biomass of maize as a result of combined use of organic and inorganic fertilizer. Pan et al. [37] also reported greater rice yield when swine manure was combined with chemical fertilizer in comparison to no fertilizer, chemical fertilizer, and rice straw. Enhanced crop productivity with organic fertilizer alone or in combination with chemical fertilizer has been ascribed to several mechanisms, including enhanced soil physical properties resulting in greater soil water and nutrient uptake by roots [16,38]. Timing of nutrient release or differences in nutrients supplied with the different amendment treatments may have added to differences in maize grain yield and biomass among treatments in this study. Substituting $50 \%$ mineral $\mathrm{N}$ by organic amendment (SC), enhanced early-release of nutrients from chemical fertilizer 
combined with delayed release of nutrients from manure. This may have enhanced synchrony between nutrient supply and crop nutrient demand, thereby reducing risk of nutrient losses and increasing crop nutrient uptake [39]. The organic manure might have provided important micronutrients and increased the soil properties, which in turn improved nutrient availability and, in combination with inorganic fertilizers, enhanced plant growth and grain yield [39]. Similarly, differences in crop-available nutrients differed between amendment treatments. Some treatments such as MS, which had a relatively high C:N ratio, likely immobilized $\mathrm{N}$, at least temporarily, thereby reducing maize $\mathrm{N}$ uptake compared to other treatments with similar $\mathrm{N}$ application [40]. The balance of organic $\mathrm{C}$ in soil is affected by rates of organic $C$ input from NPP plus amendments, and rates of soil organic $C$ decomposition. Improved soil bulk density, soil total $C$, soil hydraulic conductivity and soil water content with SC resulted to greater maize biomass production and greater NPP in comparison to NA.

\subsection{Soil Respiration}

Cumulative Rs was increased with CF, SM, MS, SC compared to NA. Application of inorganic nitrogen fertilizers together with organic materials with a low $\mathrm{C}: \mathrm{N}$ ratio can enhance mineralization in comparison to NA, thereby increasing $\mathrm{CO}_{2}$ emission [2]. In the present study, greatest Rs for all treatments occurred in July and August when maize was in the early reproductive stages. Maize aboveground biomass accumulation is rapid during these stages of phenological development [41]. This is in agreement with Qin et al. and Shi et al. [33,42], who reported increased Rs with increasing rate of crop aboveground biomass accumulation. Soil respiration values were lowest in the non-amended soils, which may be attributed to lower soil water content and maize aboveground biomass observed in this treatment. Doran et al. [43] reported declined $\mathrm{CO}_{2}$ emission as soil water content decreased. Low soil respiration rates in the no amendment treatment is an indication of little or no SOM, or soil microbial activity. It may also signify that soil conditions (soil moisture, bulk density, saturated hydraulic conductivity) were limiting biological activity.

Among the treatments that received soil amendments, CF and SC exhibited the greatest Rs throughout this study, which suggest a potential increase in labile $C$ source. The increased Rs in CF and SC could be attributed to improved crop biomass resulting in increased microbial decomposition of organic matter and root respiration. These findings contradict those of Pan et al. [37], who reported reduced $\mathrm{CO}_{2}$ emission with combined application of organic and inorganic fertilizers. The application of swine manure + chemical fertilizer was found to increase carbon emission efficiency due to improved maize yield compared with the other treatments. Application of CF, MS, and SM also significantly increased CEE compared with NA, but to a lesser extent relative to SC. This suggests that substituting $50 \%$ of mineral $\mathrm{N}$ by organic amendment (SC) may result in improved environmental sustainability and will not compromise on yield.

\subsection{Soil Properties}

Soil properties can greatly be affected by organic and inorganic fertilizer applications [44,45]. Soil bulk density and total $C$ content in the $0-5$ and 5-10 $\mathrm{cm}$ layers and $\mathrm{K}_{\text {sat }}$ differed among treatments. Improved soil conditions with soil amendment, particularly when $50 \%$ of nitrogen was substituted by organic amendment (SC), may be attributed to its effect on soil structure [46]. Asada et al. [47] also reported increased $\mathrm{K}_{\text {sat }}$ following the application of swine manure on a sandy loam soil. In the present study, treatments with soil amendment had greater soil water content in the $0-10 \mathrm{~cm}$ layer. Increased soil water availability increases the efficiency of fertilizer use in semi-arid environments such as the Loess Plateau of China in the same location where current experiment was conducted [48]. Soil water content with the SC treatment was within the range reported by Rong et al. [49] for similarly treated soil. As highlighted earlier, high soil water content in the SC treatment is attributed to improved soil structure (decreased $\rho_{b}$ and increased total porosity) and increased permeability. This is an important consideration for semi-arid environments where limited precipitation is a primary factor restricting crop yield. Soil $\mathrm{C}$ is critical to soil functioning due to its effect on physical, chemical and biological 
properties of soils [50]. In this study, the application of soil amendments increased total C in soil compared to NA, consistent with earlier studies [51]. Organic manure applied together with chemical fertilizers increased soil $\mathrm{C}$ to a greater extent relative to other amendment treatment, showing that $50 \%$ of mineral nitrogen substituted by organic amendment (SC) can be more effective in restoring soil total $\mathrm{C}$ than chemical fertilizers alone; however, this is dependent on the degree of stabilization of organic matter in the material. Decreased $\rho_{b}$ and increased soil total $C$ with SC may be a result of greater root biomass [52]. The results observed in this study demonstrate that substituting $50 \%$ of mineral $\mathrm{N}$ by organic amendment (SC) effectively improved soil conditions thereby enhancing soil fertility and improving crop productivity in semi-arid environments.

\section{Conclusions}

Application of Swine manure + chemical fertilizer increased maize grain yield, aboveground biomass, and NPP more than maize stover, swine manure and chemical fertilizer. Increased grain yield with swine manure + chemical fertilizer further contributed to increase CEE. Swine manure + chemical fertilizer also improved $\rho_{b}, \mathrm{~K}_{\text {sat }}$, and soil total C content. Improved soil properties with $50 \%$ mineral $\mathrm{N}$ substituted by organic amendment (SC) had a beneficial effect on soil water content in the 0-10 cm depth, which translated into higher biomass and grain yields from maize. Other amendment treatment performed better compared to no amendment, but to a lesser extent relative to swine manure + chemical fertilizer. These results offer new insights into the potential of organic amendments in combination with chemical fertilizer for sustainable maize production in semi-arid environments. There is a need to further conduct a thorough economic analysis of substitution of chemical fertilizers with organic amendments.

Author Contributions: S.L. and L.L. designed the experiment; S.L. and J.X. conducted the field experiment; S.L., L.L., J.A.C. and P.S.J. wrote the manuscript and all authors approved for submission of the manuscript.

Acknowledgments: The research was funded by the Research Program of the Gansu Provincial Key Laboratory of Aridland Crop Science, Gansu Agricultural University (GSCS-2019-Z04 and GSCS-2017-4), the National Natural Science Foundation of China (31761143004 and 31660373), and the Department of Education of Gansu Province (2017C-12).

Conflicts of Interest: The authors declare no conflict of interest.

\section{References}

1. Huang, G.B.; Chai, Q.; Feng, F.X.; Yu, A.Z. Effects of different tillage systems on soil properties, root growth, grain yield, and water use efficiency of winter wheat (Triticum aestivum L.) in arid Northwest China. J. Integr. Agric. 2012, 11, 1286-1296. [CrossRef]

2. Liu, J.; Li, S.; Ouyang, Z.; Tam, C.; Chen, X. Ecological and socioeconomic effects of China's policies for ecosystem services. Proc. Natl. Acad. Sci. USA 2008, 105, 9477-9482. [CrossRef] [PubMed]

3. Yin, R.; Yin, G. China's primary programs of terrestrial ecosystem restoration: Initiation, implementation, and challenges. Environ. Manag. 2010, 45, 429-441. [CrossRef] [PubMed]

4. Kemp, D.R.; Guodong, H.; Xiangyang, H.; Michalk, D.L.; Hou, F.; Wu, J. Innovative grassland management systems for environmental and livelihood benefits. Proc. Natl. Acad. Sci. USA 2013, 110, 8369-8374. [CrossRef]

5. Liu, X.E.; Li, X.G.; Hai, L.; Wang, Y.P.; Fu, T.T.; Turner, N.C.; Li, F.M. Film-mulched ridge-furrow management increases maize productivity and sustains soil organic carbon in a dryland cropping system? Soil Sci. Soc. Am. J. 2014, 78, 1434-1441. [CrossRef]

6. Ren, X.; Zhang, P.; Chen, X.; Guo, J.; Jia, Z. Effect of different mulches under rainfall concentration system on corn production in the semi-arid areas of the Loess Plateau. Sci. Rep. 2015, 6, 19019. [CrossRef] [PubMed]

7. Liu, C.A.; Jin, S.L.; Zhou, L.M.; Jia, Y.; Li, F.M.; Xiong, Y.C.; Li, X.G. Effects of plastic film mulch and tillage on maize productivity and soil parameters. Eur. J. Agron. 2009, 31, 241-249. [CrossRef] 
8. Gan, Y.T.; Siddique, K.H.M.; Turner, N.C.; Li, X.G.; Niu, J.Y.; Yang, C.Y.; Liu, L.P.; Chai, Q. Chapter seven-ridge-furrow mulching systems-an innovative technique for boosting crop productivity in semi-arid rain-fed environments. In Advances in Agronomy; Donald, L.S., Ed.; Academic Press: Cambridge, MA, USA, 2013; pp. 429-476.

9. Zhang, J.; Sun, J.S.; Duan, A.; Wang, J.L.; Shen, X.J.; Liu, X.F. Effects of different planting patterns on water use and yield performance of winter wheat in the Huang-Huai-Hai plain of China. Agric. Water Manag. 2007, 92, 41-47. [CrossRef]

10. Wang, X.L.; Li, F.M.; Jia, Y.; Shi, W.Q. Increasing potato yields with additional water and increased soil temperature. Agric. Water Manag. 2005, 78, 181-194. [CrossRef]

11. Tian, Y.; Su, D.; Li, F.; Li, X. Effect of rainwater harvesting with ridge and furrow on yield of potato in semiarid areas. Field Crops Res. 2003, 84, 385-391. [CrossRef]

12. Ren, X.L.; Jia, Z.K.; Chen, X.L.; Han, Q.F.; Han, J. Effect of corn (Zea mays L.) water and temperature of ridge and furrow planting of rainfall harvesting under simulated rainfall conditions. Sci. Agric. Sin 2008, 41, 70-77, (In Chinese with English Abstract).

13. Lin, B.; Omoju, O.E.; Okonkwo, J.U. Factors influencing renewable electricity consumption in China. Renew. Sustain. Energy Rev. 2016, 55, 687-696. [CrossRef]

14. Wang, Y.P.; Li, X.G.; Zhu, J.; Fan, C.Y.; Kong, X.J.; Turner, N.C.; Siddique, K.H.M.; Li, F.M. Multi-site assessment of the effects of plastic-film mulch on dryland maize productivity in semiarid areas in China. Agric. Meteorol. 2016, 220, 160-169. [CrossRef]

15. Zhang, S.; Li, P.; Yang, X.; Wang, Z.; Chen, X. Effects of tillage and plastic mulch on soil water, growth and yield of spring-sown maize. Soil Tillage Res. 2011, 112, 92-97. [CrossRef]

16. Cui, H.Y.; Wei-Cheng, X.U.; Sun, Y.M.; Niu, J.Y.; Fang, Z.S. Effects of different organic manures application on soil moisture, yield and quality of oil flax. J. Soil Water Conserv. 2014, 28, 307-312.

17. Bilalis, D.; Karkanis, A.; Efthimiadou, A.; Konstantas, A.; Triantafyllidid, V. Effects of irrigation system and green manure on yield and nicotine content of Virginia (flue-cured) organic tobacco (Nicotiana tabacum), under Mediterranean conditions. Ind. Crops Prod. 2009, 29, 388-394. [CrossRef]

18. Huang, L.; Yao, L.; He, Z.; Zhou, C.; Li, G.; Yang, B.; Deng, X. Roxarsone and its metabolites in chicken manure significantly enhance the uptake of as species by vegetables. Chemosphere 2014, 100, 57-62. [CrossRef]

19. Adamtey, N.; Cofie, O.; Ofosu-Budu, K.G.; Ofosu-Anim, J.; Laryea, K.B.; Forster, D. Effect of N-enriched co-compost on transpiration efficiency and water-use efficiency of maize (Zea mays L.) under controlled irrigation. Agric. Water Manag. 2010, 97, 995-1005. [CrossRef]

20. Hu, J.; Lin, X.; Wang, J.; Dai, J.; Chen, R.; Zhang, J.; Wong, M.H. Microbial functional diversity, metabolic quotient, and invertase activity of a sandy loam soil as affected by long-term application of organic amendment and mineral fertilizer. J. Soil Sediment 2011, 11, 271-280. [CrossRef]

21. Ding, W.; Cai, Y.; Cai, Z.; Zheng, X. Diel pattern of soil respiration in N-amended soil under maize cultivation. Atmos. Environ. 2006, 40, 3294-3305. [CrossRef]

22. Ren, X.; Wang, Q.; Tong, C.; Wu, J.; Wang, K.; Zhu, Y.; Lin, Z.; Watanabe, M.; Tang, G. Estimation of soil respiration in a paddy ecosystem in the subtropical region of China. Chin. Sci. Bull. 2007, 52, 2722-2730. [CrossRef]

23. Iqbal, J.; Ronggui, H.; Lijun, D.; Lan, L.; Shan, L.; Tao, C.; Leilei, R. Differences in soil CO2 flux between different land use types in mid-subtropical China. Soil Biol. Biochem. 2008, 40, 2324-2333. [CrossRef]

24. Erenstein, E.; Blümme, M.; Grings, E. Potential for dual-purpose maize varieties to meet changing maize demands: Overview. Field Crops Res. 2013, 153, 1-4. [CrossRef]

25. FAO. Soil Map of the World: Revised Legend; World Soil Resources Report 60; Food and Agriculture Organization of the United Nations: Rome, Italy, 1990.

26. Lamptey, S.; Li, L.; Xie, J.; Zhang, R.; Luo, L.; Cai, L.; Liu, J. Soil respiration and net ecosystem production under different tillage practices in semi-arid Northwest China. Plant Soil Environ. 2017, 63, 14-21.

27. Carter, M.R.; Gregorich, E.G. (Eds.) Soil Sampling and Methods of Analysis; Lewis Publisher: London, UK, 1993; p. 823.

28. Paydar, Z.; Cresswell, H.P. Water retention in Australian soils: II. Prediction using particle size, bulk density, and other properties. Aust. J. Soil Res 1996, 34, 679-693. [CrossRef] 
29. Jia, D.; Dai, X.; He, M. Polymerization of glutenin dying grain development and quality expression in winter wheat in response to irrigation levels. Crop Sci. 2012, 52, 1816-1827. [CrossRef]

30. Liu, M.; Liu, G.B.; Bu, C.F. Experimental study on soil infiltration characteristics using disc permeameter. Nongye Gongcheng Xuebao/Trans. Chin. Soc. Agric. Eng. 2002, 18, 54-58.

31. Alves, B.J.R.; Smith, K.A.; Flores, R.A.; Cardoso, A.S.; Oliveira, W.R.D.; Jantalia, C.P.J.; Urquiaga, S.; Boddey, R.M. Selection of the most suitable sampling time for static chambers for the estimation of daily mean N2O flux from soil. Soil Biol. Biochem. 2012, 46, 12-19. [CrossRef]

32. Zhai, L.M.; Liu, H.B.; Zhang, J.Z.; Huang, J.; Wang, B.R. Long-term application of organic manure and mineral fertilizer on $\mathrm{N} 2 \mathrm{O}$ and $\mathrm{CO} 2$ emissions in a red soil from cultivated maize-wheat rotation in China. J. Integr. Agric. 2011, 10, 1748-1757. [CrossRef]

33. Qin, A.; Huang, G.; Chai, Q.; Yu, A.; Huang, P. Grain yield and soil respiratory response to intercropping systems on arid land. Field Crops Res. 2013, 144, 1-10. [CrossRef]

34. Bolinder, M.A.; Janzen, H.H.; Gregorich, E.G.; Angers, D.A.; VandenBygaart, A.J. An approach for estimating net primary productivity and annual carbon inputs to soil for common agricultural crops in Canada. Agric. Ecosyst. Environ. 2007, 118, 29-42. [CrossRef]

35. Chaparro, J.; Sheflin, A.; Manter, D.; Vivanco, J. Manipulating the soil microbiome to increase soil health and plant fertility. Biol. Fertil. Soil 2012, 48, 489-499. [CrossRef]

36. Kibunja, C.N.; Mwaura, F.B.; Mugendi, D.N.; Kitonyo, E.M.; Salema, M.P. Nitrogen (N) use efficiency under continuous maize-bean cropping system in semi-humid highlands of Kenya. East Afr. Agric. For. J. 2010, 76, 115-120.

37. Pan, G.P.; Zhou, Z.; Li, S.; Pete, L.; Li, D.; Qiu, X.; Zhang, X.; Xu, S.; Shen, X.; Chen, X. Combined inorganic/organic fertilization enhances $\mathrm{N}$ efficiency and increases rice productivity through organic carbon accumulation in a rice paddy from the Tai Lake region, China. Agric. Ecosyst. Environ. 2009, 131, 274-280. [CrossRef]

38. Payne, W.A.; Hossner, L.R.; Onken, A.B.; Wendt, C.W. Nitrogen and phosphorus uptake in pearl millet and its relation to nutrient and transpiration efficiency. Agron. J. 1995, 87, 425-431. [CrossRef]

39. Kyi, M.; Kumudra, W.; Kyaw Kyaw, W.; Takeo, Y. Effects of Combined Application of Inorganic Fertilizer and Organic Manures on Nitrogen Use and Recovery Efficiencies of Hybrid Rice (Palethwe-1). Am. J. Plant Sci. 2017, 8, 1044-1064.

40. Yanni, S.F.; Whalen, J.K.; Ma, B.L. Field-grown Bt and non-Bt corn: Yield, chemical composition and decomposability. Agron. J. 2011, 103, 486-493. [CrossRef]

41. Abendroth, L.J.; Elmore, R.W.; Boyer, M.J.; Marlay, S.K. Corn Growth and Development; PMR 1009; Iowa State Univercity Extension: Ames, IA, USA, 2011.

42. Shi, P.L.; Zhang, X.Z.; Zhong, Z.M.; Ouyang, H. Diurnal and seasonal variability of soil CO2 efflux in a cropland ecosystem on the Tibetan Plateau. Agric. Meteorol. 2006, 137, 220-233. [CrossRef]

43. Doran, J.W.; Mielke, I.N.; Power, J.F. Microbial activity as regulated by soil water-filled pore space. Symposium on Ecology of Soil Microorganisms in the Microhabita Environment. In Transactions of the 14th International Congress of Soil Science; International Society of Soil Science: Kyoto, Japan, 1990; Volume III, pp. 94-99.

44. Barbera, V.; Poma, I.; Gristina, L.; Novara, A.; Egli, M. Long-term cropping systems and tillage management effects on soil organic carbon stock and steady state level of $\mathrm{C}$ sequestration rates in a semi-arid environment. Land Degrad. Dev. 2012, 23, 82-91. [CrossRef]

45. Srinivasarao, C.H.; Venkateswarlu, B.; Lal, R.; Singh, A.K.; Kundu, S.; Vittal, K.P.R.; Patel, J.J.; Patel, M.M. Long-term manuring and fertilizer effects on depletion of soil organic carbon stocks under pearl millet cluster bean-castor rotation in western India. Land Degrad. Dev. 2014, 25, 173-183. [CrossRef]

46. Mamedov, A.I. Soil water retention and structure stability as affected by water quality. Eurasian J. Soil Sci. 2014, 3, 89-94. [CrossRef]

47. Asada, K.; Yabushita, Y.; Saito, H.; Nishimura, T. Effect of long-term swine-manure application on soil hydraulic properties and heavy metal behaviour. Eur. J. Soil Sci. 2012, 63, 368-376. [CrossRef]

48. Huang, G.B.; Zhang, R.Z.; Li, G.D.; Li, L.L.; Chan, K.Y.; Heenan, P.; Chen, W.; Unkovich, M.J.; Robertson, M.J.; Cullis, B.R.; et al. Productivity and sustainability of a spring wheat-field pea rotation in a semi-arid environment under conventional and conservation tillage systems. Field Crops Res. 2008, 107, 43-55. [CrossRef] 
49. Rong, X.M.; Jian, R.; Zhu, H.; Liu, Q.F.Z.; Liu, J.; Yue, Z.H. Effects of application of inorganic fertilizer in combination with organic fertilizer to red upland soil. J. Hunan Agric. Univ. 2001, 27, 453-456.

50. Bronick, C.J.; Lal, R. Soil structure and management: A review. Geoderma 2005, 124, 3-22. [CrossRef]

51. Ding, X.L.; Han, X.Z.; Liang, Y.; Qiao, Y.F.; Li, L.J.; Li, N. Changes in soil organic carbon pools after 10 years of continuous manuring combined with chemical fertilizer in a Mollisol in China. Soil Tillage Res. 2012, 122, 36-41. [CrossRef]

52. Yeboah, S.; Lamptey, S.; Zhang, R.; Li, L. Conservation Tillage Practices Optimizes Root Distribution and Straw Yield of Spring Wheat and Field Pea in Dry Areas. J. Agric. Sci. 2017, 9, 37-48. [CrossRef] 